\title{
E-learning: An effective mode of teaching English as a Second Language
}

\section{Rosy Yumnam ${ }^{1}$ *}

${ }^{1}$ Department of English Language Education, The English and Foreign Languages University, Shillong, India

\begin{tabular}{|c|c|c|c|}
\hline Received: 05.06.2021 & Accepted: 07.07.2021 & Published: 08.08.2021 & - $\quad$ Final Version: 08.08.2021 \\
\hline
\end{tabular}

\begin{abstract}
The benefits of e-learning in teaching English as a Second Language (ESL) are huge. The outbreak of the dreaded COVID19 pandemic has forced schools, colleges and universities to temporarily remain closed to fight the contagion. E-learning or online learning is a learning method which has been employed in such a difficult scenario to continue the teaching-learning process. Elearning uses various tools and systems to optimize the teaching-learning process through online platforms. For teaching ESL, the teachers should explore collaborative learning, communicative language teaching, and communicative task-based language teaching to enable learners to effectively participate in the e-learning process. The use of these approaches engages the students to interact and perform the assigned tasks enabling them to effectively learn the language in the online platform. The paper explores the various e-learning practices into making effective teaching of English as a second language. Various e-learning tools like the internet, video conferencing platforms like Zoom, Google Meet and Webex, Google Classroom, YouTube, podcast and vodcast, online-boards, mobile phones, and social networking sites like WhatsApp, Facebook and Twitter are explored to efficiently teach English as a second language. Further, the study investigated and analyzed an ESL classroom where various e-learning tools are used.
\end{abstract}

Keywords: E-learning, E-learning tools, ESL, Learning, Teaching

\section{Introduction}

The outbreak of the dreaded COVID19 pandemic towards the end of May 2020 till the present day has brought the world to a complete and partial lockdown. It has disastrously affected every establishment and the global economy. The education sector has also been badly hit by this unprecedented pandemic. Almost all the schools, colleges, and universities are forced to temporarily remain closed to fight the contagion. In such a situation, there is a fear of losing the academic year of the students, which will further hamper their future academic life. Many of the educational establishments have discontinued in-person teaching to restrain the spread of this deadly virus. The uncertainty of getting back to the normal teaching mode has prompted educationalists to adopt various innovative teaching methods. The educational establishments are on the lookout for ways to continue the teaching-learning process. Thus, there is an urgent need to develop proper plans to save the students and the academic fraternity from the impending danger of forever depriving them of their right to learning. E-learning or online learning is one such learning method that has been employed in such a difficult scenario. The paper explores the various e-learning practices into making effective teaching of English as a second language (ESL). Various e-learning tools like the internet, video conferencing platforms like Zoom, Google Meet and Webex, Google Classroom, YouTube, podcast and vodcast, online-boards, mobile phones and social networking sites like 
WhatsApp, Facebook, and Twitter are examined to efficiently teach English as a second language. Furthermore, the study investigated and analyzed an ESL classroom where various e-learning tools are used.

\section{Literature Review}

Information and Communication Technology (ICT) can be seen as an outgrowth of modern technology's substantial progress and is increasingly becoming an integral part of our everyday lifestyles (Sahin, 2014; AlTameemy \& Alrefaee, 2021). E-learning or online learning is a new teaching-learning prospect for teachers and students to cater to an effective education process by combining computers and the internet (Jabeen \& Thom as, 2015). Chhabra (2012) asserts that:

"E-learning is a diverse range of technological tools and systems that can be utilized by capable and creative teachers to enhance teaching and learning situations. These are used to make learning more interesting, motivating, stimulating and meaningful to the students" (p. 2).

With its effective learning methods, e-learning is also used in teaching English as a second language. In language learning environments, the use of computers and the internet make way to design computer programs for language learning and teaching, which came to be known as ComputerAssisted Language Learning (CALL) (Guan, 2014). So, the use of computers and the internet in language learning and teaching created terminologies like CALL, e-learning, web-based learning, distance-learning or online learning (Gluchmanova, 2015). E-learning in ESL context can be termed as computer-enabled learning of ESL. In this teaching-learning process, the internet is used as a medium either as a main or additional educational source (Mutambik, 2018). It is believed that in traditional learning situations, spatial and temporal restrictions, if required, can be removed by elearning (Smith, 2000). In e-learning, students can learn listening, speaking, reading and written communication skills in authentic learning environments (Al-Hassan \& Shukri, 2017).

Language education has used computer-based technologies since the 1960's (Davies, 2012a). Further, the emergence of the World Wide Web increased the use of computer-based technologies in the field of education. The recognition of e-learning in English language teaching (ELT) is a pertinent component of the technological advancement (Hellebrandt, 1999). Lee et al. (2003) contended that the use of Web-based instruction programs effectively enhances the communicative skills and oral efficiency of the learners as it offers a realistic language learning environment. Chhabra (2012) asserts that in the present technological era, the use of e-learning tools in ELT with its creativity and constructive activity will make learning more effective. Mutambik (2018) in his research involving the use of e-learning in English as a Foreign Language (EFL) in Saudi Arabia establishes the importance of using e-learning systems to effectively meet the requirements of the teachers and students. Research by Erarslan and Arslan (2020) show that for a successful integration of online learning to take place, e-autonomous learning practices among the students need to be developed, and learners should be assisted to make a controlled and conscious effort. They further indicate that students could find out their effective learning styles and outcomes when they have gained e-autonomy in their online learning (Erarslan \& Arslan, 2020; Al Hadef, 2021). Zakarneh (2018) explored the effectiveness of e-learning in Arab universities and the research revealed that e- 
learning assists in acquiring vocabulary, development of the language skills and English language grammar. Ramos \& Gatcho (2020) in their research examined the common writing problems faced by Filipino freshman college students in the online learning context and found that majority of the learners are either developing or fairly developing in their writing skills. Therefore, e-learning can be effectively used in ELT. With proper planning, e-learning can make learners develop their own learning styles and also it can effectively enhance such language skills as grammar and vocabulary.

\subsection{Objective}

The objective of the paper is to explore the diverse e-learning practices into making an effective teaching of English as a second language.

\section{Methodology}

There have been several arguments associated with e-learning in the education process. Learning pedagogy, financial issues, accessibility, life-long learning, flexibility and teacher-learner competencies are some of the arguments related to e-learning pedagogy (Dhawan, 2020). Relatedly, the current COVID19 crisis has led to the argument that e-learning serves as a boon to continue the education process (Dhawan, 2020). Therefore, in view of these observations, the study tries to look at the significance of e-learning in English language teaching and learning. The study is analytical in method. It is based on secondary sources like research journals, online sources and scholarly articles and classroom observation.

The study was carried out in a university in Meghalaya, a state in Northeast India. The participants in the study were undergraduate ESL students in their semester 1 pursuing Bachelor of Arts (Honours in English) and the teacher who teaches the course. The number of student and teacher participants taken for the study is 16 and 1, respectively. The syllabus of this undergraduate course has Academic writing in semester 1 as a taught course. The duration of the study is four months. The study was conducted during the lockdown period induced by the COVID19 pandemic. The various e-learning tools like the internet, Google Classroom, Google Meet, Whats App, podcasts, vodcasts, blogger.com and YouTube were used in the course of the study.

\section{Findings and discussions}

\subsection{The use of e-learning tools in ELT}

Various e-learning tools are available. Yale Center for Language (2015) broadly grouped these elearning tools into nine: audio recording and editing, video production, photo-editing (Pixir), clear's rich internet applications (multimedia projects), vocabulary learning, video conferencing (skype), presentation (Prezi), editing (Amara), websites, word reference (collaborative working and dictionaries) and e-portfolios (weebly). Son (2011) listed some online tools which are divided into twelve kinds and they are live and virtual worlds, communication content, learning management systems, Website creation, Web exercise creation, resource sharing, dictionaries, concordancers, wikis and blogs, utilities and Web search engines. These tools are believed to improve the efficiency of e-learning. They are the facilitators of e-learning. E-learning can be grouped in two categories called synchronous and asynchronous learning. In synchronous learning, real time interaction takes place. For example, meeting and interacting with students in Zoom, Google Meet, Webex, telephone conversations and instant messaging. Asynchronous learning does not require real time. The teachers 
interact with the students through text messages, email, discussion boards, PowerPoint presentations, etc. The students can refer to the materials provided to them in their convenient time. Teachers should use both synchronous and asynchronous learning to suit the learner's needs and enhance learning. For teaching ESL, the teachers should explore collaborative learning, communicative language teaching and communicative task-based language teaching to enable learners to effectively participate in the e-learning process. The use of these approaches engages the students to interact and perform the assigned tasks enabling them to effectively learn the language in the online platform. Some of the e-learning tools to teach English as a second language are:

\section{The Internet.}

The internet has a remarkable prospect in teaching English as a second language. It has a vast source of information in various forms such as articles, courses, authentic materials, etc. With the help of the internet, online classes can be successfully conducted through online meeting platforms like Google Meet, Zoom, Webex, etc. Assignments can be sent to students through emails or they can be uploaded in Google Classroom or any Learning Management System. The students can get their assignments done through the various sources available on the internet. Online exams can also be given. The teacher can choose the difficulty level of the learners. Live interactions in online classes engage the students to practice their language skills. Various authentic materials like articles, audio-visual clips, movies, plays, etc. can be explored from the internet to teach English as a second language.

\section{Google Meet, Zoom, Webex.}

Google Meet, Zoom and Webex are video conferencing services used for business as well as online classes. They are a convenient platform as they can be logged in from a mobile phone, laptop, tablet, or computer anywhere. For online classes, these platforms can be conveniently used at the convenient time for both the teacher and the student. The teachers can interact live with their students. PowerPoint presentations and audio-video aids can be shared during the online interactions. For ESL classes, the teacher can teach speaking skills, voice modulation, phonetics, writing skills, listening skills, reading skills, and vocabulary through PowerPoint presentations and videos and audios. The students can be then asked to practice the concepts taught in the class through live interactions with their teachers. As for assessments, the students can be assigned certain topics and they can be guided to prepare PowerPoint presentations to be presented in the online platform.

\section{Google Classroom.}

In Google Classroom, the teachers can create an online classroom platform to manage files and documents for their students. What makes Google Classroom teacher-student friendly, is its incorporation of certain features like making announcements, creating assignments, storing classroom materials, and allowing students to interact efficiently. In ELT classes, the teachers can upload materials and the students can access them as and when required. Assignments and even assessments on various topics on writing skills, grammar, creative writing, vocabulary, etc., can be given and the students can upload them in the classroom. These assist the teachers in organizing their classes well and maintaining a record of the assignments given to the students. The students can also manage and access the materials uploaded by their teachers whenever they need. 


\section{Using YouTube.}

YouTube videos are a vital source of teaching English as a second language. They can be used to foster pronunciations, language skills, vocabulary, etc. through communicative language teaching approach. YouTube offers authentic examples of everyday English (Chhabra, 2012; Zitouni et al., 2021) which can benefit learners who have English as their second language. They can be effectively exploited to enhance the language skills of listening, speaking, reading and writing (Chhabra, 2012). A group activity can be given to the students where a movie clip can be shown from YouTube. Students are given some time to reflect, discuss and interact on the clip. They can then be asked to write a play based on the clip. This will greatly enhance their communicative skills, writing skills and listening skills. In another activity, a movie clip can be shown to the students. The students are guided to narrate the remaining part of the story in their own words. They are given freedom to create their own stories. This activity assists them to be creative as well as to augment their speaking skills. Similarly, there are many learning videos in YouTube which aim to enhance English language. These videos can be filtered and used efficiently in the classroom to increase the effectiveness of learning English as a second language.

\section{Online-boards.}

Interactive whiteboards are student friendly and can be used by teachers for discussions in the online classroom. They are significant in online classes as they encourage collaborative teaching and learning. They greatly enhance the effectiveness of learning during online teaching as they encourage two sided interactions. They facilitate the teaching of the language skills of listening, speaking, reading and writing. Blogging platforms such as Penzu, wikispaces, blogger, Learning Management Systems, Moodle, etc. can be effectively used in ELT. Some examples are:

- https://penzu.com

- https://webwhiteboard.com/

- writeboard.com

- https://www.blogger.com/

- https://www.wikispaces.com/content/classroom

- Edublog.com

- Wordpress.org

Teachers can encourage students to develop their own blogs. They can be guided to write on topics of their interest and share them with their classmates. Discussion of the topic can then be done in the comment section. Videos and audios can also be uploaded. This tool greatly enhances the language skills of the learners as they are actively involved in the process. The teacher can even use the interaction in the blog as a form of assessment.

\section{Mobile phones.}

Mobile phones are an exceedingly convenient learning tool in the present situation. For online classes during these unprecedented pandemic times, mobile phones have become a blessing. They facilitate live online and offline interactions. Students can log in and attend live online classes anywhere. For teaching speaking skills, the teacher can ask the students to record their own voice using their mobile 
phones on a particular topic. This can be played in the online class followed by discussions, and further comments and observations can be given by the teacher. To teach writing skills, the students can be assigned to make a short video of around ten minutes on a current topic using their mobile phones. They are asked to write the script of the video and submit it along with the video. The teacher can assess the writing skills, speaking skills as well as the creativity of the students through the script as well as the video. This can be played in the class. Further discussions can lead to enhance listening and speaking skills. The whole process encourages the students to learn new vocabulary and also develops their communicative skills.

\section{Facebook, WhatsApp and Twitter.}

The social networking applications like Facebook, WhatsApp and Twitter play a pertinent role in online teaching and learning. These are user-friendly and both teachers and students are familiar with them. The current generation of students is active on these social networking sites. So, this can be used to create an interest and motivate the students to learn English grammar, vocabulary, communicative skills and language skills. Collaborative learning can be encouraged using these tools. Communicative language teaching approach can also be used for enhancing language learning using these sites. Groups can be created using these tools which allow easy access of information and interaction. For teaching vocabulary, new words can be put up in the group and the students can be asked to make sentences of their own. These sentences can be then asked to post in the group so that the entire group can learn and enhance their vocabularies and its usage. Writing, cognitive and creative skills can also be greatly enhanced by using these social networking tools. It also becomes a platform to express their thoughts and creativity and share with the world. These tools also help teachers to extend their interaction time with the students. The students can practice speaking and writing skills at their own leisure time. Moreover, most students are active while using these social networking tools. So, they can be used to boost their morale and confidence.

\section{Podcast and Vodcast.}

Podcasts (syndicated audio files) and vodcasts (syndicated video files) are an important element in online teaching and learning. They help students to explore, observe, process and interpret. They greatly encourage collaboration and creativity. Communicative task-based teaching approach can be used to effectively enhance language learning using these tools. The teacher can record and distribute lessons through podcasts and vodcasts anytime, anywhere. The students can in turn access these materials at their own convenient time. The teachers can also share authentic materials through these tools. For ESL learners, the teachers can assign tasks like taking an interview of friends, relatives or family members about their culture. This enhances their communicative skills as well as helps in understanding the culture of that particular community. Students might be asked to share these podcasts and vodcasts in the class which may further engage them to actively participate in collaborative learning thereby enhancing their language learning process. 


\subsection{Classroom observations}

During the study, the teacher used the internet and successfully conducted the online classes. The teacher used Google Classroom, Mobile phones, YouTube and WhatsApp to send assignments, materials, podcasts, vodcasts and PowerPoint presentations. For live classes, Google Meet platform was used. The student participants used the internet to research on the topics provided to them. Active participation of the student participants in the form of PowerPoint presentations and discussions were possible through the use of the internet. The students were given the tasks to discuss on the topics assigned to them through blogger.com.

The study indicated that the use of the e-learning tools has facilitated the teaching-learning process. The student participants received the online materials well. They could research on the topics provided to them through various search engines. Their writing skills were nurtured through blogger.com. The student participants were asked to upload their writing tasks in blogger.com in the initial stage of writing. The discussion forum enabled them to critically analyse and improve their writing skills. Based on their discussions, the teacher assessed their writing skills. After the final draft was ready, the student participants made a PowerPoint presentation and presented in the class. The presentations were conducted in Google Meet. The listeners received the presentations well. The student participants felt that the discussions after the presentations were lively and interactive. The teacher assessed and gave feedback based on their academic writing skills and content. The student participants felt that the various e-learning tools have made them engage in diverse constructive activities during the lockdown. The use of the search engines has assisted them to be independent learners. The uses of blogger.com, PowerPoint presentation, podcasts and vodcasts while learning have made them explore new avenues. These enhance their creativity, critical thinking and motivation level thereby improving their academic writing skills. Relatedly, the teacher felt that the use of the various e-learning tools is a boon in these unprecedented pandemic times. The teacher found that the teaching process using e-learning tools has kept the participants engaged with their assignments. Some drawbacks were also observed in this process. Both the students and teacher felt that the internet connectivity was often not reliable. Some of the students found it difficult to attend the live online classes as they were stationed in places with little or no internet connectivity. In the beginning, the teacher found it difficult to use these tools. However, after some online research and assistance from family members, the teacher could actively and effectively conduct the classes. The teacher and the students were of the opinion that the absence of physical presence greatly made a void in the teaching-learning process. They felt that peer interaction and discussions were more effective in the physical classroom. However, in the current difficult circumstance, both the teacher and the student participants felt that e-learning is the only way to continue the teaching-learning process.

\section{Conclusion}

The benefits of e-learning in ELT are immensely huge. But, e-learning may pose various challenges towards its effective implementation. Some of the challenges are teacher and learner competencies, connectivity issues and financing issues for procuring its technological devices. However, under this unfortunate pandemic situation, e-learning seems to be the only alternative to continue the teachinglearning process. E-learning, therefore, should be encouraged by trying to overcome the various difficulties. In ELT, teachers should encourage the use of collaborative learning, communicative language teaching and communicative task-based language teaching to ensure active participation of the learners in the e-learning mode. As the tasks and activities involve the learners to perform and 
complete the assigned work, the objective of learning ESL is achieved. The various e-learning tools create ample constructive and creative opportunities for the learners to effectively learn the language. The teachers have to be creative and explore the diverse e-learning tools to engage the students into learning the language. In the study, it is found that the use of the e-learning tools has facilitated the teaching-learning process in the ESL classroom. It has greatly enhanced the motivation level, creativity and critical thinking of the student participants. The study also indicated some challenges in using the e-learning tools like internet connectivity and effectiveness of peer interactions. Notwithstanding the various challenges, both the teacher and the student participants felt that elearning is the only way to continue the teaching-learning process in the present unprecedented COVID19 crisis.

\section{References}

[1] Al Hadef, S. (2021). The Implication of Online Learning on the Motivation of Students: (Students of University Mohammed First as a Case Study). International Journal of Linguistics and Translation Studies, 2(3), 12-22. https://doi.org/10.36892/ijlts.v2i3.164

[2] Al-Hassan, S., \& Shukri, N. (2017). The Effect of Blended Learning in Enhancing Female Students' Satisfaction in the Saudi Context. English Language Teaching, 10(6), 190. https://doi.org/10.5539/elt.v10n6p190

[3] AlTameemy, F. A., Alrefaee, Y. (2021). Impact of Covid-19 on English Language Teaching in Yemen: Challenges and Opportunities. TESOL International Journal, 16 (4.4). 238-252

[4] Chhabra, P. (2012). Use of E-learning tools in teaching English. http://www.researchmanuscripts.com/isociety2012/9.pdf

[5] Davies, G. (2012a). Computer Assisted Language Learning: Where are we now and where are we going? http://www.camsoftpartners.co.uk/docs/UCALL_Keynote.htm

[6] Dhawan, S. (2020). Online Learning: A Panacea in the time of COVID19 Crisis. https://journals.sagepub.com/doi/full/10.1177/0047239520934018

[7] Erarslan, A. \& Arslan, A. (2020). Online Learning Experiences of University Students in ELT and the Effects of Online Learning on their Learning Practices. https://www.researchgate.net/publication/343678780_Online_Learning_Experiences_of_University_Stud ents_in_ELT_and_the_Effects_of_Online_Learning_on_their_Learning_Practices

[8] Gluchmanova, M. (2015). Application of e-learning in foreign language teaching at the technical university. Procedia - Social and Behavioral Sciences, 174, 3144-3149.

[9] Guan, S. (2014). Internet-based technology use in second language learning: A systematic review. International Journal of Cyber Behavior, Psychology and Learning, 4(4), 69-81.

[10] Hellebrandt, J. (1999). Virtual Collaborations in The Spanish Class: From E-Mail To Web Design and CdRom Development. Journal of Educational Computing Research, 20(1), 59-70. https://doi.org/10.2190/6BQA-UHYL-4JJK-V1R4

[11] Jabeen, S. S., \& Thomas, A. J. (2015). Effectiveness of online language learning. Proceedings of the World Congress on Engineering and Computer Science, 1, 1-5.

[12] Lee, C., \& Pyo, K. (2003). A study on the effectiveness of online/offline English language learning at university level. Multimedia- Assisted Language Learning, 6(1), 90-110.

[13] Mutambik, I. (2018). The Role of E-learning in Studying English as a Foreign Language in Saudi Arabia: Students' and Teachers' Perspectives. https://files.eric.ed.gov/fulltext/EJ1176493.pdf

[14] Raheem, R. B. \& Khan, A. (2020). The role of E-learning in COVID-19 crisis. https://www.researchgate.net/publication/340999258_THE_ROLE_OF_E-LEARNING_IN_COVID19_CRISIS

[15] Ramos, E. T. B. \& Gatcho, A. R. G. (2020). Common Writing Problems and Writing Attitudes among Freshman University Students in Online Learning Environments: An Exploratory Study. jtls.sabapub.com

[16] Sahin, A. (2014). The Role of Information and Communication Technologies in schools: Perspectives of teachers. International Journal of Academic Research in Progressive Education and Development, 3(2), $112-124$. 
[17] Son, J. (2011). Online Tools for Language Teaching, Teaching English as a Second or Foreign Language. http://www.teslej.org/wordpress/issues/volume 15/ej57/ ej57int/

[18] Yale Centre for Language (2015). Online Teaching Tools and Resources. http://cls.yale.edu/onlineteaching-toolsresources

[19] Zakarneh, B. (2018). Effectiveness of E-learning Mode for Teaching English Language in Arab Universities.https://www.researchgate.net/publication/333040198_Effectiveness_of_Elearning_Mode_for_Teaching_English_Language_in_Arab_Universities

[20] Zitouni, M., Al-Traif, H., Zemni, B., Mohammed, O.S., Aljasser, M. (2021).Utilization of youtube to improve the pronunciation skill of Saudi learners in translation departments. Asian ESP Journal 17(2), 133-154

\section{Author Bio data}

Dr. Rosy Yumnam is an Assistant Professor in the Department of English Language Education, The English and Foreign Languages University, Shillong, India. Her research and publications address language, culture and pedagogy, teaching language skills, production of ELT materials and academic writing. She has edited a book, titled, Language and Discourse: Culture, Literature and Pedagogy in North East India (Magnolia Publication). Her latest book is Culture in English Language Teaching: The use of the Puyas in the English Language Classroom (Mittal Publication). 